\title{
A family showing no evidence of linkage between the ataxia telangiectasia gene and chromosome $11 \mathrm{q} 22-23$
}

\author{
D Hernandez, C M McConville, M Stacey, C G Woods, M M Brown, P Shutt, \\ G Rysiecki, A M R Taylor
}

\begin{abstract}
We have studied an inbred family in which two cousins presented with the same clinical features of ataxia telangiectasia (AT). Both patients are still ambulatory at ages 25 and 20. Cellular features of both patients are typical of $\mathrm{AT}$ and include increased radiosensitivity and an increased level of spontaneously occurring chromosome aberrations in peripheral blood lymphocytes. Linkage studies and haplotype analysis show no clear evidence that the gene for AT in this family is on chromosome 11q22-23. As previously reported AT families from complementation groups $A B, C$, and $D$ have all shown linkage to this region of 11q22-23. Our study is of importance in suggesting additional locus heterogeneity.

(f Med Genet 1993;30:135-40)
\end{abstract}

Ataxia telangiectasia (AT) is a recessively inherited disorder showing progressive cerebellar degeneration in which patients are predisposed to developing lymphoid tumours. ${ }^{12}$ A gene for ataxia telangiactasia has been mapped to chromosome $11 \mathrm{q} 22-23,,^{3-5}$ a region associated with neurological and immune function loci. In view of reports of at least four complementation groups, AB, C, D, and $E,{ }^{5 a}$ there may be a number of genes in this chromosome segment. It is clear, however, that the AT locus for patients in groups AB, and $C$ is at $11 \mathrm{q} 22-23^{36}$ and both may be between NCAM/DRD2 and STMY/D11S385. Fibroblasts from a group D patient have been complemented by chromosome 11 microcell fusion ${ }^{89}$ and the group $\mathrm{D}$ gene may be distal to $T H Y-1$ between D11S147 and D11S133.710 One group E family we have studied did not provide any support for the existence of this AT locus outside the $11 \mathrm{q} 22-23$ region. ${ }^{5}$

In addition to the evidence for genetic heterogeneity as shown by complementation, there is also evidence for cellular heterogeneity in AT. About 10 to $15 \%$ of subjects show a much smaller increase in radiosensitivity compared with other AT patients as measured chromosomally and by colony forming assays. ${ }^{11} 12$

The clinical features of AT are progressive cerebellar ataxia, oculomotor apraxia, an expressionless face, choreoathetosis, dysarthria, peripheral neuropathy, and ocular telangiectasia. ${ }^{1}$ Clinical heterogeneity may be observed. The progressive cerebellar degeneration usually begins in infancy or early childhood ${ }^{1}$ but the age of onset may vary up to the age of about 12 years. ${ }^{13}$ The rate of progress of the disorder may be variable and the presence of bulbar telangiectasia is also variable.

In the present study we describe a large family with two adult cousins with ataxia telangiectasia with a slightly milder clinical course. Genetic linkage analysis has not provided any evidence that the gene for $\mathrm{AT}$ in this family is located at $11 \mathrm{q} 22-23$.

\section{Case reports}

The proband (II.7) was a 25 year old woman and the youngest of eight sibs in a family in which the parents were first cousins and part of a large inbred family. She was unsteady from the age of 3 to 4 years but was still able to run in later childhood, although her walking was ataxic. She was short ( $>-2$ SD for age), had vertical nystagmus, slow saccadic eye movements, slight choreiform movements of the arms, intention tremors, absent ankle reflexes, and flexor plantars. Dysarthria was present, developing in the teenage years. No cutaneous or ocular telangiectasia was evident. CT scan showed enlargement of the fourth ventricle and widening of all cerebellar fissures. AFP and immunoglobulin levels were normal. There was no intellectual impairment.

Her male cousin (II.8) presented at the age of 3 to 4 years with an ataxic gait and constant drooling. At the age of 20 he had progressive unsteadiness in walking, dysarthria, drooling, vertical nystgamus and loss of pursuit movements, choreiform movement of the hands, moderate peripheral ataxia, dysdiadochokinesis, absent ankle reflexes, flexor plantars, decreased sensitivity to vibration and pinprick, and pes cavus. A CT scan showed atrophy of the posterior fossa structures. There was no cutaneous telangiectasia. AFP and immunoglobulin levels were normal.

The remainder of the sibs and the four parents were examined and were normal (fig 1). One cousin of I.2 has Wilson's disease.

\section{Materials and methods}

CELLS AND CULTURE CONDITIONS

A normal skin fibroblast strain Con $\mathrm{Bu}$, together with the classical AT fibroblast strain AT3BI and cells from the two patients II.7 and II.8, were grown in Dulbecco's modified Eagles medium (DME) supplemented with $10 \%$ FCS (Flow Laboratories), glutamine, 
I

II

\begin{tabular}{|c|c|}
\hline TYR & 2 \\
\hline D11S84 & 22 \\
\hline D11S36 & 12 \\
\hline D11S35 & 12 \\
\hline STMY & 12 \\
\hline D11S385 & 1 \\
\hline D11S384 & 2 \\
\hline D11S535 & 22 \\
\hline D11S424 & 2 \\
\hline D11S132 & 12 \\
\hline DRD2 & 12 \\
\hline NCAM & 2 \\
\hline D11S351 & 1 \\
\hline D11S144 & 1 \\
\hline APOA 1 & 2 \\
\hline D11S29 & 1 \\
\hline CD3 & 1 \\
\hline D11S382 & 1 \\
\hline$T H Y-1$ & 2 \\
\hline D11S528 & 2 \\
\hline ETS1 & 21 \\
\hline
\end{tabular}

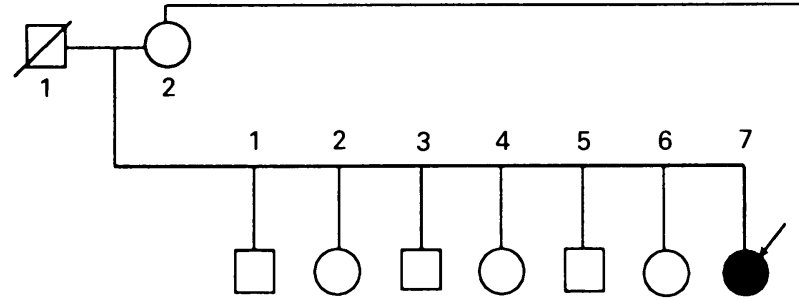

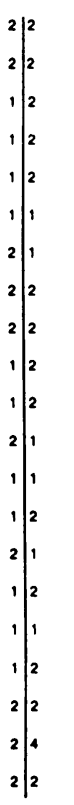

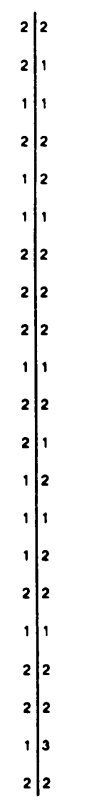

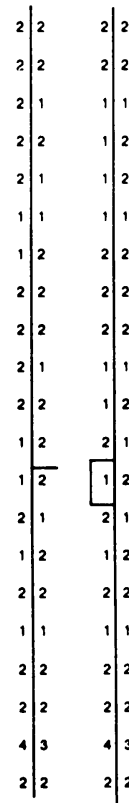

\begin{tabular}{l|l}
2 & 2 \\
2 & 1 \\
1 & 2 \\
2 & 2 \\
2 & 2 \\
2 & 2 \\
1 & 2 \\
1 & 2 \\
1 & 2 \\
2 & 2 \\
1 & 2 \\
1 & 2 \\
2 & 2 \\
2 & 3 \\
2 & 2
\end{tabular}

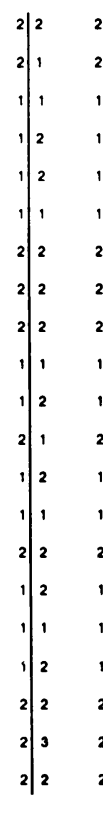

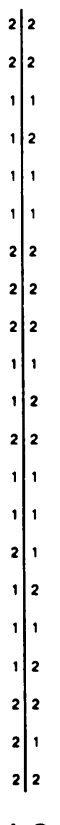

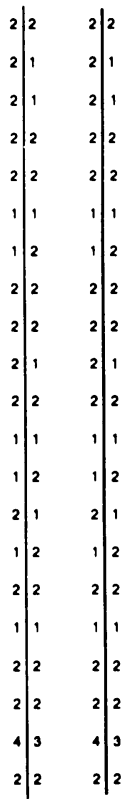

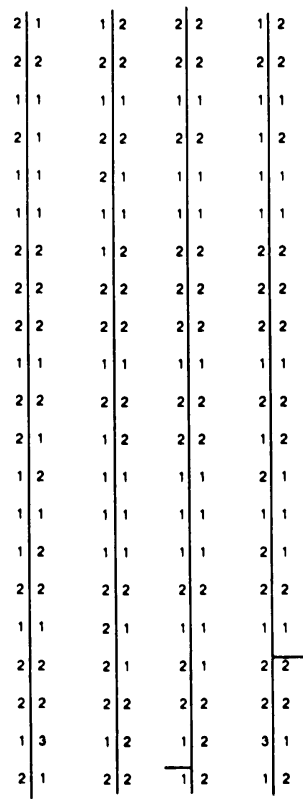

CE FG C/E G E G/F

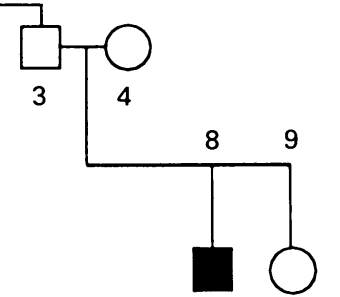

Figure 1 Pedigree of a family showing two cousins with ataxia telangiectasia. Haplotypes are given for all family members across a region of chromosome 11q22-23 between tyrosinase and ETS.

penicillin $(100 \mathrm{IU} / \mathrm{ml})$, and streptomycin $(100 \mu \mathrm{g} / \mathrm{ml})$ and incubated at $37^{\circ} \mathrm{C}$ in $5 \% \mathrm{CO}_{2}$ in air.

\section{COLONY FORMING ASSAYS}

Different cell dilutions irradiated with doses of $\gamma$ rays between 1.00 and 5.00 Gray were seeded on to lethally irradiated feeder layers of the same cells $\left(6 \times 10^{4}\right.$ per $9 \mathrm{~cm}$ dish irradiated with 35 Gray $\gamma$ rays). Cells were left for 14 to 21 days in an incubator to form colonies with a change of medium once a week and were then stained with methylene blue and counted.

\section{HUMAN-HAMSTER CELL HYBRIDS}

Mononuclear cells separated from whole blood were fused with hamster a23 cells in 50\% PEG 1000 for approximately one minute. Adherent hybrid colonies were selected in HAT medium. (Non-adherent lymphocytes were washed away.)

\section{CHROMOSOME PREPARATIONS}

For lymphocyte chromosome preparations $0.4 \mathrm{ml}$ of heparinised whole blood was cultured in $4.0 \mathrm{ml}$ of RMPI 1640 supplemented with $10 \%$ FCS, streptomycin, and penicillin. Cultures were fixed at 72 hours. Lymphocytes were also irradiated four hours before harvest at 72 hours (in the $G_{2}$ phase of the cell cycle). A Pantak constant potential industrial radio- graphy unit at $245 \mathrm{kev} / 12 \mathrm{~mA}$ and half value thickness copper filter of $1 \mathrm{~mm}$ was used. The filter object distance was $30 \mathrm{~cm}$ and the dose rate $1.01 \mathrm{Gray} / \mathrm{minute}$.

For trypsin banded chromosomes, slide preparations were incubated for one hour at $95^{\circ} \mathrm{C}$, immersed in Hanks Balanced salt solution $(1: 1 \times 10 \mathrm{HBSS} / \mathrm{x} 1 \mathrm{HBSS})$ for 10 minutes, washed in pH 6.8 buffer, immersed in $2.8 \%$ trypsin in buffer for about 50 seconds, and rinsed in saline. Metaphases were stained with $20 \%$ Leishman's stain in $\mathrm{pH} 6.8$ buffer for about four minutes.

\section{DNA MARKERS}

The 11q22-23 markers used are given in table 1. Inserts were isolated from vector sequences by gel purification in all cases. When inserts contained repeated sequences, only a part of the insert corresponding to single copy sequence was used.

DNA PREPARATIONS AND ANALYSIS

DNA used for analysis of polymorphisms was extracted from blood samples according to the method of Kunkel et $a l^{14}$ and digested with restriction enzymes using the manufacturer's recommended conditions. II. 6 and II.7 were sampled on two separate occasions and reanalysed. Southern blotting, probe radiolabelling, and hybridisation were carried out as previously described. ${ }^{4}$ Enzymes used to detect polymorphisms are given in table 1 . 
Table 1 Restriction fragment length polymorphisms detected by chromosome 11q22.23 probes.

\begin{tabular}{|c|c|c|c|c|}
\hline Locus & Probe & Enzyme & Alleles (kb) & Frequency \\
\hline$T Y R$ & pTyrs-33 & TaqI & $2 \cdot 8 / 2 \cdot 4$ & $0.52 / 0.48$ \\
\hline$D 11 S 84$ & p2-7-1D6 & TaqI & $6 \cdot 4 / 4 \cdot 2$ & $0 \cdot 28 / 0 \cdot 72$ \\
\hline$D 11 S 36$ & $\Phi 2 \cdot 14$ & RsaI & $2 \cdot 95 / 2 \cdot 10$ & $0.59 / 0.41$ \\
\hline$D 11 S 35$ & $\Phi 2 \cdot 22$ & $M s p \mathrm{I} / T a q \mathrm{I}$ & $4 \cdot 4 / 4 \cdot 2$ & $0 \cdot 49 / 0 \cdot 51$ \\
\hline$S T M Y$ & STMY cDNA & $\operatorname{Taq} \mathbf{I}$ & $4 \cdot 6 / 2 \cdot 1+1 \cdot 0$ & $0 \cdot 54 / 0 \cdot 46$ \\
\hline$D 11 S 385$ & pCJ52.75 & MspI & $5 \cdot 5 / 3 \cdot 5+2 \cdot 0$ & $0 \cdot 89 / 0 \cdot 11$ \\
\hline$D 11 S 384$ & cCJ52.193 & TaqI & $8 \cdot 5 / 4 \cdot 3$ & $0 \cdot 26 / 0 \cdot 74$ \\
\hline D11S535 & pJ12.8 & $X m n \mathrm{I}$ & $3 \cdot 8 / 2 \cdot 8$ & $0.67 / 0.33$ \\
\hline$D 11 S 424$ & pCJ 52.77 & $M s p$ & $7 \cdot 3 / 6 \cdot 8$ & $0 \cdot 25 / 0 \cdot 75$ \\
\hline D11S132 & CRI-L424 & $E c o$ RI & $9 \cdot 0 / 6 \cdot 7+2 \cdot 3$ & $0.54 / 0.46$ \\
\hline$D R D 2$ & $\lambda \mathrm{hD} 2 \mathrm{DG} 1$ & TaqI & $6 \cdot 6 / 3 \cdot 7+2 \cdot 9$ & $0 \cdot 24 / 0 \cdot 76$ \\
\hline$N C A M$ & pHFM 1 & BamHI & $9 \cdot 8 / 6 \cdot 3+3 \cdot 8$ & $0 \cdot 77 / 0 \cdot 23$ \\
\hline$D 11 S 351$ & pCJ 52.208 & $M s p I$ & $4 \cdot 0 / 3 \cdot 2$ & $0.41 / 0.59$ \\
\hline$D 11 S 144$ & pYNB3.12 & $M s p \mathbf{I}$ & $2 \cdot 8 / 2 \cdot 4$ & $0.55 / 0.45$ \\
\hline$A P O A 1$ & ApoAI & Sst II & $4 \cdot 2 / 3 \cdot 2$ & $0.96 / 0.04$ \\
\hline$D 11 S 29$ & pL7 & TaqI & $13 \cdot 9 / 10 \cdot 9 / 9 \cdot 2$ & $0 \cdot 23 / 0 \cdot 76 / 0 \cdot 01$ \\
\hline$C D 3 E$ & pDJ4 & TaqI & $8 \cdot 7 / 8 \cdot 1$ & $0.67 / 0.33$ \\
\hline$D 11 S 382$ & cCJ $52 \cdot 12$ & TaqI & $2 \cdot 8 / 2 \cdot 4$ & $0.18 / 0.82$ \\
\hline$T H Y-1$ & pGSEBg.4 & $M s p \mathrm{I}$ & $0.9 / 0.8$ & $0.28 / 0.72$ \\
\hline ETS & pHE5.4 & AvaII & $2 \cdot 4 / 2 \cdot 2$ & $0 \cdot 19 / 0 \cdot 81$ \\
\hline$D 11 S 528$ & \multicolumn{4}{|c|}{ epeat (see Materials and methods) } \\
\hline
\end{tabular}

The primers used to amplify the microsatellite repeat at the locus D11S528 were as follows: primer $420265^{\prime}$ AATGGTGTCCCCACACATGT, primer 42027 5' TCCTACCTACCGAGCTTAAA. ${ }^{15}$ Primer 42027 was end labelled with $30 \mu \mathrm{Ci} \gamma^{32} \mathrm{P}$ ATP using $10 \mathrm{U}$ polynucleotide kinase and purified by centrifugation through a sephadex G25 column. Polymerase chain reaction was carried out in a $25 \mu \mathrm{l}$ volume containing $200 \mathrm{ng}$ of genomic DNA template, $10 \mathrm{pmol}$ each of the labelled and unlabelled primers, $200 \mu \mathrm{mol} / 1$ each of dATP, dCTP, and dTTP, $0.5 \mathrm{U}$ of Taq polymerase (Boehringer) and Taq polymerase buffer (Boehringer). Samples were processed through 36 cycles consisting of 45 seconds at $94^{\circ} \mathrm{C}$ (three minutes for cycle 1 ), 30 seconds at $52^{\circ} \mathrm{C}$, and 30 seconds at $72^{\circ} \mathrm{C}$ (five minutes for cycle 36$)$. Aliquots of the PCR reactions $(2 \mu \mathrm{l})$ were mixed with $8 \mu \mathrm{l}$ formamide sample buffer, denatured at $94^{\circ} \mathrm{C}$ for three minutes, and 3 to $4 \mu \mathrm{l}$ electrophoresed on a $6 \%$ denaturing polyacrylamide sequencing gel. Gels were fixed, dried, and autoradiographed for 15 hours using X-OMAT AR film (Kodak).

\section{LINKAGE ANALYSIS}

The two point and multipoint analyses were performed using LINKAGE. ${ }^{16}$ Published values for maker allele frequencies (HGM10) were used in linkage calculations. The AT gene frequency was set to 0.003 and the gene assumed to be fully penetrant. A 2:1 ratio of female:male recombination was used as suggested from previous results. ${ }^{5}$

\section{DNA FINGERPRINTING}

DNA samples from lymphoblastoid cell lines ( 5 to $8 \mu \mathrm{g}$ ) were digested overnight with HinfI (New England Biolabs) and analysed on $0.7 \%$ agarose gels in TBE containing $0.5 \mu \mathrm{g} / \mathrm{ml}$ ethidium bromide. Gels were run at $75 \mathrm{~V}$ until a $2.3 \mathrm{~kb}$ marker fragment had migrated $20 \mathrm{~cm}$. Gels were treated with $0.25 \mathrm{~mol} / 1 \mathrm{HCl}(15$ minutes), $0.5 \mathrm{~mol} / 1 \mathrm{NaOH}, 1.5 \mathrm{~mol} / 1 \mathrm{NaCl}$ (30 minutes), and $0.5 \mathrm{~mol} / 1$ Tris $\mathrm{HCl} \mathrm{pH} 7.5$, $3 \mathrm{~mol} / 1 \mathrm{NaCl}$ (30 minutes). Blotting on to Hybond $\mathrm{N}$ (Amersham) and UV fixation were carried out according to manufacturers' instructions.

Multilocus probes (MLPs) $33 \cdot 15$ and $33 \cdot 6^{17}$ were labelled and hybridised to membranes. Following stripping $\left(30\right.$ minutes at $45^{\circ} \mathrm{C}$ in $0.4 \mathrm{~mol} / 1 \mathrm{NaOH}$, followed by 30 minutes at $45^{\circ} \mathrm{C}$ in $0.2 \mathrm{~mol} / 1$ Tris $\mathrm{pH} 7.5,0.1 \%$ SDS, $0.1 \times$ SSC), membranes were rehybridised with cocktails of single locus probes (MS8, MS43A, and $\mathrm{p} \lambda 3$ or MS31 and MS1). Single locus probes were labelled by random hexamer priming. Prehybridisation was in $0.5 \mathrm{~mol} / 1$ $\mathrm{Na}_{2} \mathrm{HPO}_{4}, 7 \%$ SDS, $1 \mathrm{mmol} / 1$ EDTA, 0.1\% $\mathrm{BSA}$ for 20 minutes at $65^{\circ} \mathrm{C}$, and hybridisation was in $1 \times$ SSC, $6 \%$ PEG 6000 for 15 hours at $65^{\circ} \mathrm{C}$. Washing was carried out at $65^{\circ} \mathrm{C}$ in $40 \mathrm{mmol} / 1 \mathrm{Na}_{2} \mathrm{HPO}_{4} \mathrm{pH} \cdot 2,0 \cdot 1 \%$ SDS (15 minutes) followed by $0.5 \times \mathrm{SSC}, 0.01 \% \mathrm{SDS}$ $(2 \times 15$ minutes $)$ and $0.2 \times$ SSC $0.01 \%$ SDS $(2 \times 15$ minutes). Autoradiography was carried out at $-70^{\circ} \mathrm{C}$ using Amersham Hyperfilm MP. ${ }^{17 a}$

\section{Results}

In addition to the clearcut clinical features of AT we also show that these patients have the typical cellular features of AT.

\section{PRESENCE OF SPONTANEOUS CHROMOSOME}

ABNORMALITIES IN LYMPHOCYTES

One of the characteristic features of AT lymphocytes and a useful diagnostic aid is the presence of translocation chromosomes, especially involving chromosomes 7 and 14 in about $10 \%$ of circulating $\mathrm{T}$ lymphocytes. ${ }^{18-20}$ In the present patients II.7 and II.8, 4/50 and $4 / 50$ cells respectively showed the presence of translocations or deletions as shown in table 2. Only one of these translocations, $t(7 ; 14)$ (q35;q11) in patient II.8, is typical of AT. The remaining chromosome translocations and deletions are more unusual. The telomeric fusion in patient II.8 is not unusual in AT patients but they are normally associated with the presence of large translocation clones of lymphocytes. ${ }^{21}$ No such clonal development was seen in lymphocytes from these patients. There was no evidence of a constitutional rearrangement or deletion at $11 \mathrm{q} 22-23$ in patients II.7 and II.8.

CHROMOSOMAL RADIOSENSITIVITY IN PATIENTS II.7 AND II.8

After exposure of lymphocytes to both 0.5 Gray and 1.0 Gray $x$ rays in the $G_{2}$ phase of the cell cycle, both patients showed the large in-

Table 2 Chromosome rearrangements observed in 50 cells from each of two $A T$ homozygotes.

\begin{tabular}{lll}
\hline Patient & Rearrangement & No of cells \\
\hline II.7 & $46, \mathrm{XX}, \mathrm{t}(2 ; 6)(\mathrm{p} 21 ; \mathrm{pter})$ & 1 \\
& $46, \mathrm{XX}, \operatorname{del}(7)(\mathrm{qter} \rightarrow \mathrm{p} 15:)$ & 1 \\
& $46, \mathrm{XX},-15,-15, \mathrm{t}(19 ;$ ?) & 1 \\
II.8 & $46, \mathrm{XX}, \mathrm{t}(7 ; 14)(\mathrm{p} 15 ; \mathrm{q} 32)$ & 1 \\
& $46, \mathrm{XY}, \mathrm{t}(7 ; 14)(\mathrm{q} 35 ; \mathrm{q} 11)$ & 1 \\
& $46, \mathrm{XY}, \mathrm{t}(19 ; ?)$ & 1 \\
& $46, \mathrm{XY}, \operatorname{dic}(20 ; 21)$ (qter;pter) & 1 \\
& $46, \mathrm{XY}, \operatorname{tr}(3 ; 4)$ & 1 \\
\hline
\end{tabular}


crease in induced chromatid type damage, compared with a normal control (table 3), which is typical of AT patients. No other family member tested showed the increased radiosensitivity. In particular lymphocytes from unaffected sib II.6 were compared with those from affected sib II.7 after exposure to $\gamma$ rays and shown not to have increased radiosensitivity (table 3 )

COLONY FORMING ABILITY OF CULTURED SKIN FIBROBLASTS FROM PATIENTS II.7 AND II.8 AFTER EXPOSURE TO $\gamma$ RAYS

The colony forming ability of fibroblasts from patients II.7 and II.8 are shown in fig 2 together with normal fibroblasts and cells from AT3BI, a classical AT patient from complementation group AB. Clearly the survival of cells of II.7 and II.8 is greatly reduced compared with normal and no different from AT3BI.

LOCALISATION OF THE AT GENE IN THIS FAMILY We typed each family member for 21 markers (table 1) at 11q22-23 and haplotypes together with the family pedigree are given in fig 1 . The results were used to compute pairwise lod scores between each marker and AT and were also used in a multipoint analysis. Markers D11S385, D11S535, D11S424, CD3, and $T H Y-1$ were uninformative. Significant negative lod scores $(\leqslant-2)$ were obtained for markers D11S84, STMY/D11S85, NCAM/ $D R D 2, D 11 S 351 / D 11 S 144$, and ETS1. The highest pairwise lod scores were obtained with $D 11 S 35(\mathrm{Z}=0.41$ at $\theta=0), D 11 S 36(\mathrm{Z}=0.26$ at $\theta=0)$, and $D 11 S 132(Z=0.26$ at $\theta=0)$. Location scores (fig 3) showed significant negative values when $\mathrm{AT}$ was placed at $\theta=0$ from $D 11 S 351 / D 11 S 144, N C A M / D R D 2$, and $S T M Y / D 11 S 385$. For the intervals in between scores were mostly negative, only exceeding zero when close to $T H Y-1$. The reason for this could be the uninformativity of this marker and the large interval between ETS1 and THY-1. Using the more distal marker D11S528, which has been mapped between $E T S$ and $T H Y-1$, we could show that II.6 and II.7 had identical alleles, which were

Table 3 Induced chromosome damage following exposure at $G_{2}$ to ionising radiation.

\begin{tabular}{lccccccccc}
\hline Patient & $\begin{array}{c}\text { No of } \\
\text { cells }\end{array}$ & r & dic & f & ctg & ctb & csg & tri & qr \\
\hline After exposure to & 0.5 Gray $x$ rays & & & & & & & & \\
ATII.7 & 50 & 0 & 0 & 9 & 64 & 14 & 0 & 2 & 4 \\
ATII.8 & 50 & 0 & 1 & 4 & 44 & 19 & 0 & 0 & 0 \\
Normal & 50 & 0 & 0 & 0 & 8 & 0 & 0 & 0 & 0 \\
After exposure to 1.0 Gray & x rays & & & & & & & & \\
AT11.7 (i) & 50 & 0 & 0 & 9 & 107 & 52 & 0 & 7 & 2 \\
(ii) & 50 & 0 & 0 & 8 & 110 & 38 & 0 & 5 & 1 \\
ATII.8 & 50 & 0 & 2 & 5 & 88 & 29 & 0 & 7 & 2 \\
II.1 & 50 & 0 & 0 & 1 & 8 & 0 & 0 & 0 & 0 \\
II.3 & 50 & 0 & 0 & 0 & 9 & 0 & 0 & 0 & 0 \\
II.4 & 50 & 0 & 0 & 0 & 7 & 2 & 0 & 0 & 0 \\
AT 3BI & 50 & 1 & 2 & 7 & 58 & 40 & 0 & 2 & 4 \\
Normal & 50 & 0 & 0 & 1 & 8 & 0 & 0 & 0 & 0 \\
After exposure to 1.0 Gray $\gamma$ rays & & & & & & & & \\
ATII.6 & 20 & 0 & 0 & 0 & 16 & 5 & 0 & 0 & 0 \\
ATII.7 & 20 & 0 & 0 & 3 & 46 & 32 & 0 & 3 & 1 \\
\hline
\end{tabular}

$r=$ rings, dic $=$ dicentrics, $f=$ fragment, $c t g=$ chromatid gaps, $c t b=$ chromatid breaks, $\mathrm{csg}=$ chromosome gaps, $\mathrm{tri}=$ triradials, $\mathrm{qr}=$ quadriradials. (i) and (ii) are different sample times.

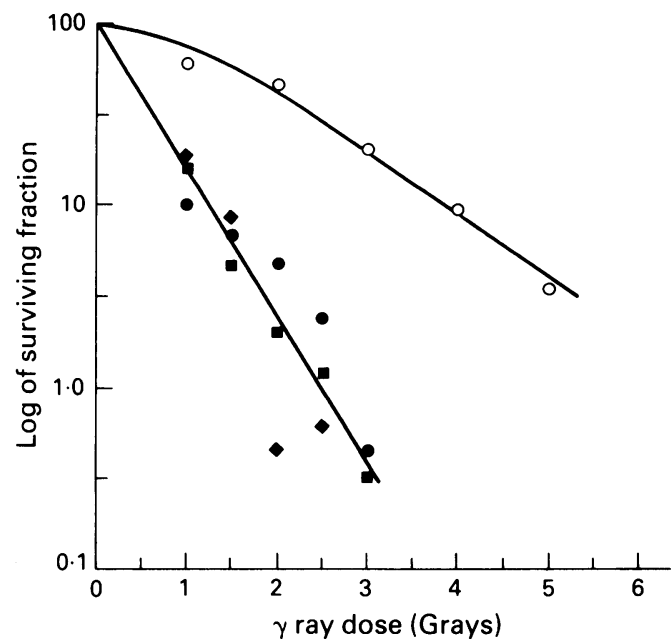

Figure 2 Survival of skin fibroblasts from the two cousins II.7 (filled circles) and II.8 (diamonds) after exposure to $\gamma$ rays. Survival of cells from group $A A T$ patient $A T 3 B I$ (filled squares) and a control (open circles) are also shown.

different from II.8. This suggests there is indeed no linkage of $A T$ with $T H Y-1$ or the more distal marker D11S528 in this family.

If the AT gene were on this region of chromosome 11 in this family we would expect (1) that patient II.7 would have a unique haplotype around the AT gene compared with her unaffected sibs, and (2) I.2 and I.3 would share a common region of chromosome 11 near the AT gene and this same chromosome would be present in the two patients. Inspection of the haplotypes showed the reasons for the negative lod scores obtained, in that patient II.7 and her unaffected sib II. 6 have identical haplotypes. The two affected cousins, II.7 and II.8, also show very little haplotype similarity. Haplotype C shown by I.2 and I.3 has only been inherited by II.8 and not by II.7. Neither of the predictions were therefore observed. Since all possible haplotype combinations are represented (in the larger side of the family) in normal sibs the AT gene is unlikely to be in phase with either C or D maternal haplotypes. There is no evidence to support the hypothesis that the AT gene is located in this region of chromosome 11 in this family.

Other explanations for these observations have been considered, but are regarded as unlikely. (1) The possibility of a mix up in the bloods was eliminated by repeating the typings of II. 6 and II.7 on DNA from a second blood sample. The duplicate samples confirmed that both sibs have identical haplotypes. In addition, DNA from sibs II. 6 and II.7 were shown to be quite distinct since the sibs could be shown to have inherited different alleles for non-chromosome 11 markers. The maternally derived haplotype was checked by isolating the maternal chromosome $\mathrm{D}$ from II.4 in a human/hamster hybrid cell line and the typing repeated. This yielded the same alleles as the derived haplotype. (2) The possibility of nonpaternity was also considered. The use of various multilocus probes, biallelic probes, and hypervariable probes suggested that this was unlikely. Multilocus probes were used to calculate percentage band share. The expected 


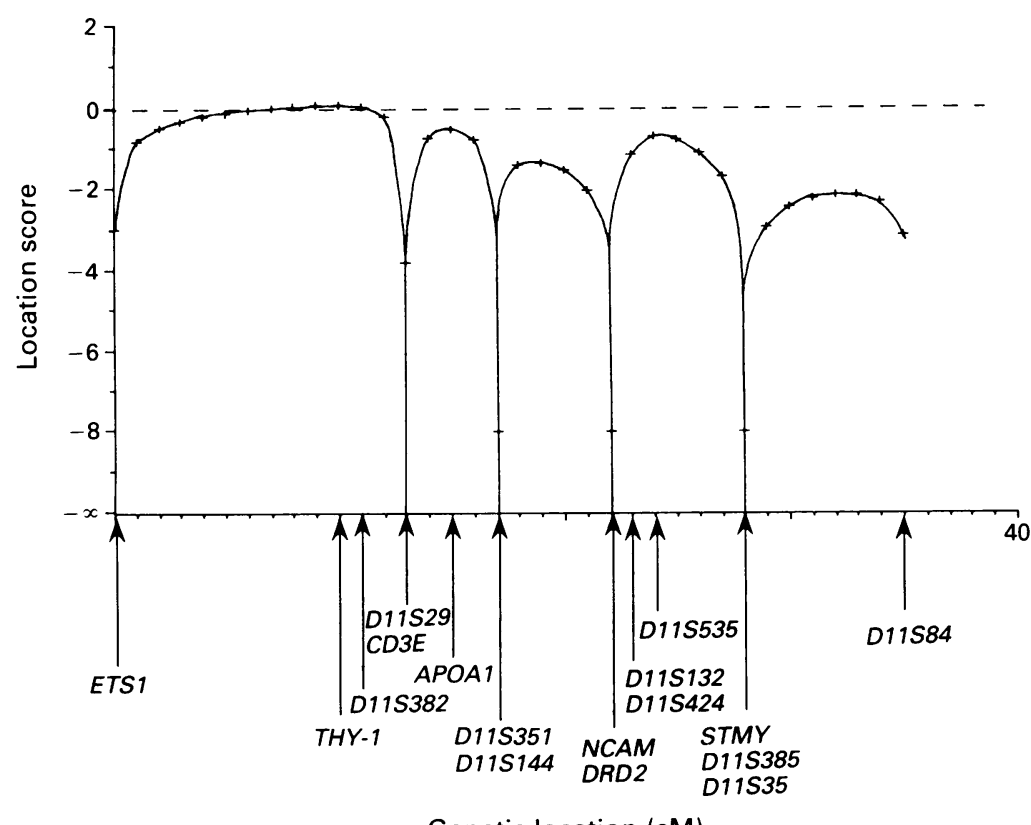

Genetic location (cM)

Figure 3 Location scores for a seventeen point map. (D11S528, D11S384, D11S36, and tyrosinase were not included because of lack of information on their precise location.)

value for first degree relatives on average is $62.5 \%$, II.6 and II.7 shared $64.0 \%$ of their bands, which is consistent with a first degree relationship such as full sibs. The single locus analysis showed the presence of 17 bands within the sibship from the five probes used. If all the sibs share the same parents we would expect a maximum of 20 bands. The presence of more than 20 bands would indicate that one or more of the sibship had a different parent from the rest. Overall, these results support the hypothesis that II.6 and II.7 are full sibs. We cannot absolutely rule out non-paternity but clearly this is very unlikely. A major disparity, however, between the affected cousins is that II.7 does not show haplotype C, which is a maternal chromosome. (3) There is a possibility that there is a submicroscopic deletion in one of the chromosomes of II.7 which would make her hemizygous for the AT allele, while her normal sib, II.6, has a normal allele, giving her a normal phenotype. An alternative might be that a rare double recombination might have occurred between the maternal chromosomes, whereby II.7 inherited part of chromosome $\mathrm{C}$ with the mutant allele. Both a double recombination and deletion would explain the apparent haplotype identity between II.6 and II.7 and lack of similarity between II.7 and II.8. The combination of B/ $\mathrm{C}$ is, however, already observed in sib II.1 for the region above $N C A M / D R D 2$ with no phenotypic effect. The combination $\mathrm{B} / \mathrm{C}$ below $N C A M / D R D 2$ is, however, not seen in any of the normal sibs, and so a rare genetic event such as a double recombination or gene conversion might have occurred in this region.

It is striking, however, that two observations consistent with the AT gene being on chromosome 11 in this inbred family are (1) that both of the sibs I.2 and I.3 with AT children share the same chromosome (C in I.2), and (2) that patient II.8 is homozygous for all 16 markers between tyrosinase and $C D 3$ inclusively. On the smaller side of the family, the haplotypes are consistent with the gene being on chromosome 11 .

\section{Discussion}

The two AT patients described here are clinically unusual in still being ambulatory at the ages of 25 and 20 respectively, even though ataxic gait was first noted between the ages of 3 and 4 in both. Neither patient had evidence of cutaneous or bulbar telangiectasia, but all the remaining clinical features of AT were present: progressive cerebellar ataxia, dysarthria, flexor plantar responses, choreoathetoid movements, odd eye movements, an expressionless face, drooling (in II.8), and short stature (in II.7). AFP levels were normal in both patients. Qualitatively some of the spontaneous chromosome aberrations in both patients were different from other patients, but increased radiosensitivity was typical of AT patients. Both the cellular features and clinical features were therefore still typical of ataxia telangiectasia.

In this inbred family it was expected that both affected subjects would show similar haplotypes and a high degree of homozygosity. Ninety percent homozygosity was observed in patient II. 8 but not in II.7. Patient II.8 inherited chromosome $\mathrm{C}$, which both parents of the AT children also shared but was not present in II.7. In the larger side of the family, II.7 showed the same haplotype as a phenotypically normal sib, II.6. In 50 families haplotyped this is the only instance we have encountered where an apparently identical haplotype in unaffected and affected subjects cannot easily be explained on the basis of a single recombination event ${ }^{5}$ (unpublished results). The proband II.7 has not inherited the maternal chromosome C which in her cousin appears to contribute to AT, but instead has a different haplotype. One explanation of this is that she is homozygous for a gene at a different locus, and therefore the extended family may be carrying more than one mutation for AT. If separate loci were responsible for the AT seen in this family then phenotypic differences might be expected between the cousins. Minor differences, for example, height and drooling, exist, but the similarities appear stronger, and this especially applies to the cellular radiosensitivity.

The possibility of a rare double recombination between the maternal chromosomes would theoretically explain the haplotype similarity between II. 6 and II.7 and the difference from II.8. The recombination would have to occur telomeric to $N C A M / D R D 2$ because the combination $\mathrm{B} / \mathrm{C}$ in this region is the only haplotype not presented in an unaffected subject. This is of interest because haplotype analysis of other reported families probably places $\mathrm{AT}$ group $\mathrm{AB}$ and group $\mathrm{C}$ centromeric to $N C A M / D R D 2 .{ }^{57}$ Some evidence suggests that the locus for complemen- 
tation group $\mathrm{D}$ patients may be in the more telomeric region ${ }^{10}$ between markers D11S147 and $D 11 S 133$, which are distal to $T H Y-1 .^{7} \mathrm{We}$ do not know if our patients II.7 or II. 8 belong to complementation group D but our evidence suggests that the AT gene in this family is not linked to $T H Y-1$ or $D 11 S 528$ distal to it.

The AT homozygotes in this family appear to show a slower or less severe cerebellar degeneration compared with many other patients as judged by their degree of mobility at their age. In the family described here clinical features are milder than usual but with the presence of a typically high level of radiosensitivity. Other patients appear to have smaller increases in radiosensitivity as measured chromosomally or by cell survival, but as severe or possibly more severe cerebellar ataxia than seen here in patients II.7 and II.8. There does not appear to be a quantitative relationship between the degree of cerebellar ataxia and the level of radiosensitivity in AT patients. It is possible therefore that other genes may in some circumstances selectively modify either the radiation response or the cerebellar degeneration in different AT patients. A similar degree of radiosensitivity is seen in patients with Nijmegen breakage syndrome (NBS), but in the absence of any cerebellar ataxia. ${ }^{22}$ Cells from NBS patients, however, complement AT patients' cells suggesting the presence of a different gene producing increased radiosensitivity. ${ }^{22}$ There may therefore be several genes producing a phenotype with increased radiosensitivity with or without ataxia.

At present the simplest way in which to interpret the observations presented here is that in this family the gene for AT is not on chromosome $11 \mathrm{q} 22-23$.

We thank the Cancer Research Campaign and the Ataxia Telangiectasia Society of UK for financial support. DH holds a CRC studentship. We also thank Janet Gunn for typing and Sue Williams for photography. Multilocus probes 33.6 and 33.15 are the subject of patent no GBA 2166445 and worldwide patents (pending) for commercial diagnostic use.

1 Boder E. Ataxia telangiectasia: an overview. In: Gatti RA, Swift M, eds. Ataxia telangiectasia: genetics, neuropathology and immunology of a degenerative disease of childhood. logy and immunology of a degenerative
New York: Alan R Liss, 1985:1-63.
2 Spector BD, Filipovich AH, Perry GS, Kersey JH. Epidemiology of cancer in ataxia telangiectasia. In: Bridges BA, Harnden DG, eds. Ataxia telangiectasia. A cellular and molecular link between cancer, neuropathology and Gatti RA, Berkel I, Boder E, et al. Localisation of an ataxia telangiectasia gene to chromosome 11q22-23. Nature 1988;336:577-80.

4 McConville CM, Woods CG, Farrall M, Metcalfe JA, Taylor AMR. Analysis of 7 polymorphic markers at chromosome 11 q22-23 in 35 ataxia telangiectasia families; further evidence of linkage. Hum Genet 1990;85:215-20.

5 McConville CM, Formstone CJ, Hernandez D, Thick J, Taylor AMR. Fine mapping of the chromosome 11q2223 region using PFGE, linkage and haplotype analysis: localisation of the gene for ataxia telangiectasia to a $5 \mathrm{cM}$ region flanked by NCAM/DRD2 and STMY/CJ52.75, Ф2.22. Nucleic Acids Res 1990;11:4335-43.

5a Murnane JP, Painter RB. Complementation of the defects of DNA synthesis in irradiated and unirradiated ataxia telangiectasia cells. Proc Natl Acad Sci USA 1982; 79:1960-3.

6 Ziv Y, Rotman G, Frydman M, et al. The A-TC (ataxia telangiectasia complementation group $C$ ) locus localises to $11 \mathrm{q} 22-23$. Genomics 1991;9:373-5.

7 Sobel E, Lange E, Jaspers NGJ, et al. Ataxia telangiectasia: linkage evidence for genetic heterogeneity. Am $\mathcal{J}$ Hum Genet 1992;50:1343-8.

8 Komatsu K, Kodama S, Okumura Y, Koi M, Oshimura M. Restoration of radiation resistance in ataxia telangiectasia Restoration of radiation resistance in ataxia telangiectasia
cells by the introduction of normal human chromosome cells by the introduction of no
11 . Mutat Res 1989;253:59-63.

9 Lambert C, Schultz RA, Smith M, et al. Functional complementation of ataxia telangiectasia group D (A-TD) cells by microcell mediated chromosome transfer and mapping of the A-TD locus to a region 11q22-23. Proc Natl Acad Sci USA 1991;88:5907-11.

10 Kapp LN, Painter RB, Yu LC, et al. Cloning of a candidate gene for ataxia telangiectasia group D. Am $\mathcal{f}$ Hum Genet 1992;51:45-54.

11 Cox R, Hosking P, Wilson J. Ataxia telangiectasia, evaluation of radiosensitivity in cultured skin fibroblasts as a diagnostic test. Arch Dis Child 1978;53:386-90.

12 Taylor AMR, Flude E, Laher B, et al. Variant forms of ataxia telangiectasia. $\mathcal{f}$ Med Genet 1987;24:669-77.

13 Woods CG, Taylor AMR. Ataxia telangiectasia in the British Isles: the clinical and laboratory features of 70 British Isles: the clinical and laboratory featu
affected individuals. $O F$ Med 1992;298:169-79.

14 Kunkel LM, Smith KP, Bayer SH, et al. Analysis of human $\mathrm{Y}$ chromosome specific reiterated DNA in chromosome variants. Proc Natl Acad Sci USA 1975;74:1245-9.

15 Hauge XY, Evans GA, Litt M. Dinucleotide repeat polymorphism at the D11S528 locus. Nucleic Acids Res 1991;19:1964.

16 Lathrop GM, Lalouel JM, Julier C, Ott J. Strategies for multi-locus linkage analysis. Proc Natl Acad Sci USA 1984;81:3443-6.

17 Jeffreys AJ, Wilson V, Thein SL. Hypervariable minisatellite regions in human DNA. Nature 1985;314:67-73.

17a Ferrie RM, Smith H, Downes EA, McKechnie D, Little S. Repeat unit multipriming and hybridisation, a novel method for the production of DNA fingerprints using minisatellite probes. Nucleic Acids Res 1991;19:2505.

18 Hecht F, McCaw BK, Koler RD. Ataxia telanciectasia. Clonal growth of translocation lymphocytes. $N$ Engl $\mathcal{f}$ Med 1973;289:286-91.

19 Oxford JM, Harnden DG, Parrington JM, Delhanty JDA. Specific chromosome aberrations in ataxia telangiectasia cells. F Med Genet 1975;12:251-62.

20 Taylor AMR. Cytogenetics of ataxia telangiectasia. In: Bridges BA, Harnden DG, eds. Ataxia telangiectasia. A cellular and molecular link between cancer, neuropathology and immune deficiency. New York: John Wiley, 1982:5382.

21 Taylor AMR, Metcalfe JA, McConville CM. Increased radiosensitivity and the basic defect in ataxia telangiectasia. Int $\mathcal{F}$ Radiat Biol 1989;56:667-84.

22 Jaspers NGJ, Gatti RA, Baan C, Linssen PCML, Bootsma D. Genetic complementation analysis of ataxia telangiectasia and Nijmegen breakage syndrome in a survey of 50 patients. Cytogenet Cell Genet 1988;49:259-63. 